Indonesian Journal of Islamic Communication, Vol. 2, No. 2, Desember 2019: 105-130

\title{
ETIKA KOMUNIKASI PEMIMPIN PERSPEKTIF HADITS
}

Indonesian Journal of Islamic Communication

\author{
Rofiq Hidayat \\ Dosen Program Studi Manajemen Pendidikan Islam Fakultas Tarbiyah \\ dan Ilmu Keguruan Institut Agama Islam Negeri Jember
}

Diunggah 01 Desember / Direvisi 2 Desember / Diterima 6 Desember 2019

\begin{abstract}
Abstrac: In this paper, the author presents a study of the ethics of leader communication based on the behavior of the Prophet through the hadith. This research method uses descriptive qualitative by collecting the hadiths in the kutubut tis'ah. Based on the types of communication, the traditions related to the ethics of communication verbally and nonverbally will be examined. From the results of the study, there are three hadiths that discuss the ethics of verbal communication, namely first, not too fast, clear, firm, secondly repeat until understanding, third, only speak necessary, begin and end with basmalah, and not insulting and hadith which discusses four the thing in non-verbal communication is the hadith regarding body language, signs, deeds, and objects.
\end{abstract}

Keywords; Ethics, Communication, Leader, Hadith

Korespondensi: Rofiq Hidayat

Dosen Program Studi Manajemen Pendidikan Islam Fakultas Tarbiyah dan Ilmu Keguruan Institut Agama Islam Negeri Jember

elishaqy@yahoo.com 


\section{A. PENDAHULUAN}

Pemimpin adalah puncak dari sebuah organisasi. Idealnya seorang pemimpin harus bisa merencanakan, memberi arahan dan perintah yang tepat kepada bawahannya, serta mengambil keputusan yang penting dalam organisasinya. Menurut Greatman Theory, pemimpin yang ideal dan karismatik ada berdasarkan warisan atau ada sejak lahir, namun menurut Skill Theory, pemimpin bisa juga diciptakan berkat latihan dan pengalaman yang seimbang. ${ }^{1}$ Sedangkan menurut Imam al Ghazali, sosok pemimpin ideal adalah pemimpin yang tertanam dalam dirinya tiga hal, yaitu ilmu pengetahuan, agama, dan akhlak. ${ }^{2}$ Gus Muwafik juga memberikan pandangannya mengenai pemimpian yang ideal selain harus beriman dan bertakwa, yaitu harus jujur (shiddiq), terpercaya (amanah), punya kemampuan (fathanah), komunikatif (tabligh). ${ }^{3}$ Pentingnya komunikasi tersebut tentu harus diimbangi dengan tata cara komunikasi yang efektif dan efisien.

Namun faktanya, banyak pemimpin yang masih belum memiliki etika dalam komunikasi baik dengan bawahan, kolega, maupun atasan dari pemimpin tersebut. Ditambah dengan era globalisasi saat ini dimana komunikasi dengan memanfaatkan teknologi, tanpa etika dalam komunikasi banyak melahirkan pemimpin yang semaunya sendiri atau sak karepe dewe. ${ }^{4}$ Apalagi jika melihat realitas sekarang banyak pemimpin itu berusia lanjut, sementara bawahannya masih muda (biasa disebut dengan generasi milenial) maka akan terjadi bias komunikasi. Hal itu, menurut Alo Liliweri, karena pemimpin tersebut bekerja dengan orang-orang yang memiliki gaya komunikasi berbeda. ${ }^{5}$ Fakta di lapangan juga banyak ditemukan banyaknya pemimpin yang justru masih muda. Nadiem Makarim salah satu contoh Menteri Pendidikan dan Kebudayaan yang diangkat oleh Presiden Jokowi padahal masih 35 tahun. ${ }^{6}$ Atau Risa Santoso, rektor ITB Asia Malang yang diangkat menjadi rektor pada usia 27 tahun sehingga menjadikannya sebagai rektor termuda di

\footnotetext{
${ }^{1}$ K. H. Timotius, Kepemimpinan dan Kepengikutan.Teori dan Perkembangannya, (Yogyakarta:CV Andi Offset, 2016), 136-142

${ }^{2}$ Ade Afriansyah, Konsep Pemimpin Ideal Menurut Al-Ghazālī, Jurnal NALAR Vol 1, No 2, (Palangkaraya:IAIN Palangka Raya, 2017), 91-92.

${ }^{3}$ Muhammad Ainur, Gus Muwafik, (Yogyakarta:Laksana, 2019), 119

${ }^{4}$ M. Nur Prabowo Setyabudi dan Albar Adetary Hasibuan, Pengantar Studi Etika Kontemporer, (Malang:UB Press, 2017), 6

${ }^{5}$ Alo Liliweri, Komunikasi AntarPersonal, (Jakarta:Kencana, 2015), 276-277.

${ }^{6}$ Wahyunanda Kusuma Pertiwi, Profil Menteri Pendidikan Nadiem Makarim, Lulusan Harvard yang Dirikan Gojek, https://tekno.kompas.com/read/2019/10/23/09431827/profil-menteri-pendidikan-nadiem-makarimlulusan-harvard-yang-dirikan-gojek (diunduh tanggal 16 Nopember 2019)
} 
Indonesia. $^{7}$ Meski muda, namun keduanya harus tetap memperhatikan etika komunikasi bagaimana berbicara atau memberi arahan (perintah) kepada bawahan yang jauh lebih tua.

Jika dibiarkan tanpa etika komunikasi yang baik, maka pemimpin tersebut akan banyak menemui masalah dikemudian hari. Wayan Gede Suparthahal dan Desak Ketut Sintaasih menyebutkan bahwa Fungsi kepemimpinan terdapat tugas sebagai manajer, diantaranya mencakup tugas memotivasi karyawan, mengarahkan bawahan, memilih saluran komunikasi yang paling efektif, serta memecahkan konflik-konflik. Fungsi kepemimpinan dapat juga dikatakan sebagai proses mempengaruhi kebiasaan-kabiasaan orang lain guna mencapai tujuan organisasi. Hal ini dapat meliputi komunikasi tentang tugas pekerjaan kepada para karyawan dan juga metode-metode untuk menyelesaikan tugas-tugas tersebut. Termasuk pula dalam fungsi ini adalah sikap pimpinan yang dijadikan sebagai panutan para karyawan. Oleh karena itu sikap pemimpin harus konsisten dan selaras dengan rencana organisasi. ${ }^{8}$ Tanpa etika komunikasi yang baik, tentunya akan memberi dampak buruk baik untuk lembaga yang dipimpinnya maupun dengan masyarakat di luar lembaga. Diantaranya kurangnya koordinasi ${ }^{9}$ dan fokus pada hal-hal negatif ${ }^{10}$ karena kesalahfahaman komunikasi sejak awal. Penelitian Aras Aira terhadap para manajer dinas kabupaten Kampar dari 18 Satuan Kerja Perangkat Daerah membuktikan bahwa etika kerja berpengaruh signifikan positif terhadap kinerja manajerial. Di mana etika kerja merupakan sikap kepribadian, watak, karakter serta keyakinan atas sesuatu. Sikap ini tidak hanya dimiliki oleh individu, tetapi juga oleh kelompok, bahkan masyarakat. Etika dibentuk oleh kebiasaan, pengaruh budaya serta sistem nilai yang diyakini. ${ }^{11}$ Hasil serupa juga diperoleh dari penelitian Siti Arni Basir, dkk pada pemimpin Johor Corporation yang melaksanakan etika kerja islam dimana hasil penelitian tersebut terdapat enam peranan penting dalam melaksanakan etika

\footnotetext{
${ }^{7}$ Muhammad Aminuddin, Potret Risa Santoso, Rektor Cantik Termuda di Indonesia, https://news.detik.com/fotonews/d-4775596/potret-risa-santoso-rektor-cantik-termuda-di-indonesia, (diunduh tanggal 16 Nopember 2019)

${ }^{8}$ Wayan Gede Supartha dan Desak Ketut Sintaasih, Pengantar Perilaku Organisasi Teori, Kasus, dan Aplikasi Penelitian (Denpasar:CV Setia Bakti, 2017), 3.

${ }^{9}$ Hadi Satyagraha, Kekeliruan Manajer, (Jakarta: PT Elex Media Komputindo, 2015), 157.

${ }^{10}$ Alo Liliweri, Komunikasi AntarPersonal Opcit. Hal. 248-249

${ }^{11}$ Aras Aira, Pengaruh Etika Kerja terhadap Kinerja Manajerial pada Satuan Kerja Perangkat Daerah (SKPD)

Kabupaten Kampar, Jurnal Kutubukhanah, Vol. 19 No. 1, (Pekanbaru:UIN SUSKA, 2016), 108-110
} 
kerja silam yaitu latihan, komunikasi, pembuatan keputusan, pemantauan, sistem ganjaran, dan persekitaran. ${ }^{12}$

Richard West dan Lynn H. Turner menuliskan bahwa baik di barat maupun di Timur, telah menekan etika dalam tradisi moral mereka. Salah satu hal yang paling berpengaruh dalam etika komunikasi adalah agama. ${ }^{13}$ Dalam agama islam, etika komunikasi pemimpin juga diatur agar selaras dengan al Quran dan hadits, apalagi sebagai pemimpin, ia juga sebagai teladan yang akan dicontoh oleh bawahannya sebagaimana dalam firman Allah:

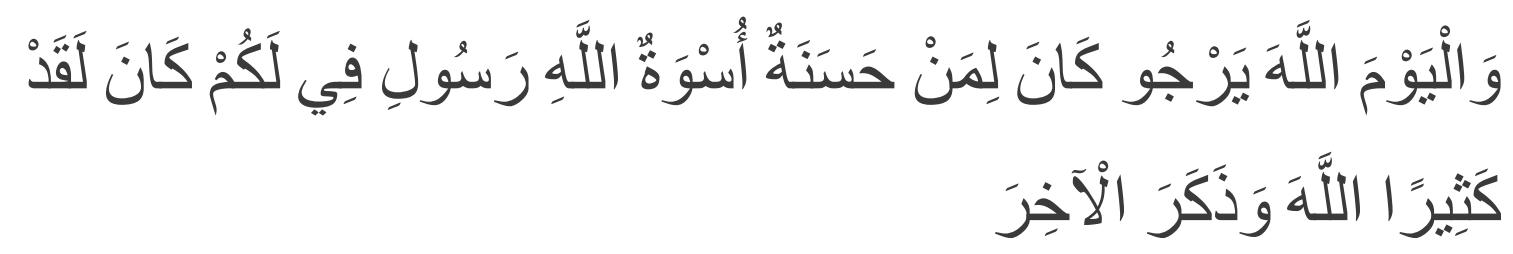

Artinya:"Sesungguhnya telah ada pada (diri) Rasulullah itu suri teladan yang baik bagimu (yaitu) bagi orang yang mengharap (rahmat) Allah dan (kedatangan) hari kiamat dan dia banyak menyebut Allah." (QS Al Ahzab:21)

Ayat tersebut menjelaskan betapa Rasulullah adalah sosok yang tepat untuk dijadikan teladan sebagai pemimpin. Apalagi banyak hadis-hadis yang menerangkan bagaimana Rasulullah bisa menjalankan etika komunikasinya dengan sebaik-baiknya, baik dalam bentuk verban maupun nonverbal sehingga menjadi acuan bagi pemimpin dunia untuk berkomunikasi. Dengan demikian perlu bagi seorang pemimpin, terutama pemimpin lembaga keagamaan Islam (seperti Kyai, Kepala Madrasah, Kepala KUA, Hakim, dan lainnya) untuk kembali berpedoman pada etika komunikasi dalam perspektif nabi. Sehingga sebagai pemimpin bisa menerapkan etika komunikasi yang baik dan benar secara islami. Karena itulah tulisan kali ini akan memaparkan bagaiman etika komunikasi pemimpin perspektif hadits.

\section{B. PEMBAHASAN}

\section{Rasulullah Sebagai Pemimpin Yang Komunikatif}

\footnotetext{
12 Siti Arni Basir, dkk, Peranan Pemimpin dalam Pelaksanaan Etika Kerja Islam: Kajian Kes di Johor Corporation (JCorp), Jurnal Usuludin 44 (Kuala Lumpur:University of Malaya, 2016), 45-48

${ }^{13}$ Richard West dan Lynn H. Turner, Pengantar Teori Komunikasi, Edisi 3, Teori dan Aplikasi, terj. Maria Natalia Damayanti Maer. (Jakarta:Salemba Humanika, 2008), 19.
} 
Salah satu sifat utama yang harus dimiliki seorang rasul adalah tabligh, yaitu menyampaikan. Menurut Dodo Murtado, dkk., sifat tabligh Rasululullah sebagai seorang pemimpin diterjemahkan dalam bahasa manajemen sebagai supel, cerdas, deskripsi tugas, delegasi wewenang, kerja tim, cepat tanggap, koordiniasi, dan supervisi. ${ }^{14}$ Seperti utusan lainnya, Rasulullah juga dibekali sifat tabligh yang bisa menjadi perantara dalam menyampaikan pesan Allah kepada umatnya. Karena itulah Rasulullah haruslah seorang komunikator. Sedangkan komunikasi yang dilakukan dalam menyampaikan hadits, maka menurut Diana Ariswanti Triningtyas adalah komunikasi ke atas. Hal itu terjadi karena komunikasi mengalir dari tingkat yang lebih tinggi dalam kelompok atau organisasi. Namun pesan yang digunakan memberikan umpan balik berdasarkan masalah-masalah yang dihadapi. ${ }^{15}$ Rachmat Kriyantono mengatakan bahwa Rasulullah adalah komunikator yang hebat. Hal itu karena tujuan komunikasi beliau adalah menyampaikan ajaran tauhid agar umat bertakwa kepada Allah. ${ }^{16}$ Prinsip ini selaras dengan misi Rasulullah dalam firman-Nya:

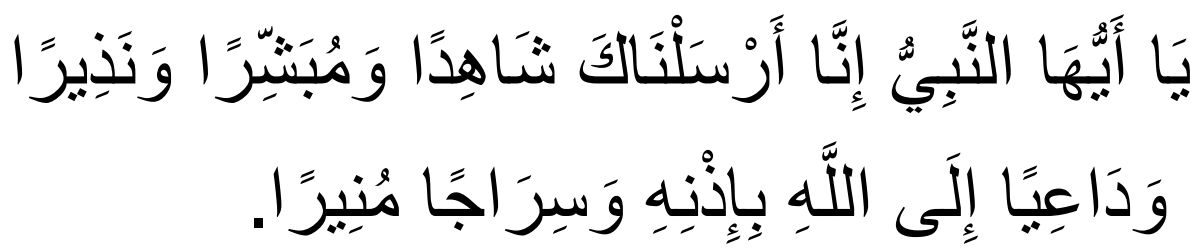

Artinya: "Hai Nabi, sesungguhnya Kami mengutusmu untuk jadi saksi dan pembawa kabar gembira dan pemberi peringatan, dan untuk jadi penyeru kepada agama Allah dengan izin-Nya dan untuk jadi cahaya yang menerangi." (QS. Al Ahzab:45-46).

Berdasarkan ayat tersebut, jelas salah satu tugasnya adalah untuk berkomunikasi dengan umatnya. Banyak hadits yang menceritakan cara nabi dalam berkomunikasi berdasarkan etika komunikasi dalam Al Quran. Ikrar menuturkan bahwa etika komunikasi al Quran tersebut berdasarkan kepada karakteristik kejujuran dalam komunikasi, prinsip lemah lembut, dan dengan metode pendekatan hikmah dan mauidhoh hasanah. ${ }^{17}$ Apalagi kedudukan hadits

\footnotetext{
${ }^{14}$ Dodo Murtado, dkk. Manajemen dalam Perspektik Al Quran dan Hadits, (Bandung:Yrama Widya, 2019), 116153.

${ }^{15}$ Diana Ariswanti Triningtyas, Komunikasi Antar Pribadi, (Magetan:Ae Media Grafika, 2016), 20

${ }^{16}$ Rachmat Kriyantono, Pengantar Lengkap Ilmu Komunikasi Filsafat dan etika ilmunya serta perspektif Islam, (Jakarta:Prenadamedia Group, 2019), 347

${ }^{17}$ Ikrar, "Konsepsi Etika Komunikasi Menurut Al-Qur'an (Suatu Kajian Tafsir Tematik)", Tesis Pascasarjana UIN Alauddin Makassar, Makassar, 2012), 84-95
} 
sebagai sumber hukum agama Islam setelah al Quran, sehingga apa yang dilakukan nabi menjadi sumber rujukan dalam beretika di masyarakat. M. Najmi Fathoni merumuskan strategi komunikasi model sang nabi pada saat bertatap muka sebagai berikut:

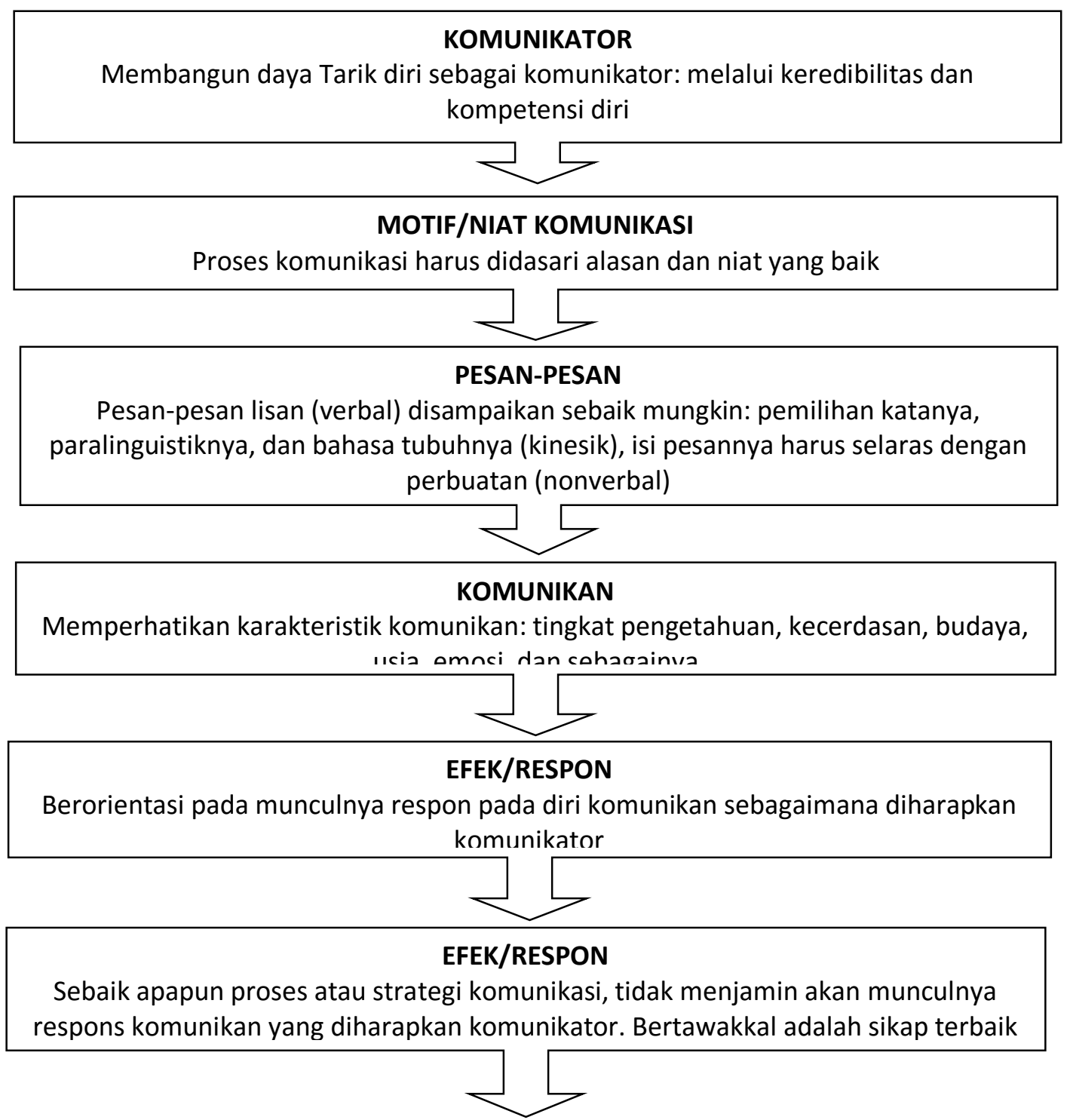

Gambar 1. Strategi komunikasi Rasulullah ${ }^{18}$

Dari gambar tersebut, M. Najmi Fathoni memaparkan bahwa strategi komunikasi nabi tersebut merupakan bentuk kecerdasan nabi dalam menghadapi umat-umatnya (bangsa arab pada masa itu) yang memang tekenal keras wataknya namun dapat bersatu. Hal penting yang dikuasai Rasulullah adalah kemampuan dan kecerdasan beliau dalam mengenali komunikan. Rasulullah mampu memperhatikan karakteristik komunikan, yaitu tingkat pengetahuan, kecerdasan,

${ }^{18}$ M. Najmi Fathoni, Strategi Komunikasi Model Sang Nabi,(Jakarta:Gramedia, 2017), xxiv 
budaya, usia, emosi, dan sebagainya. Banyak hadits yang menerangkan bagaimana etika nabi dalam berkomunikasi dengan malaikat Jibril saat berwujud seorang pemuda, atau bagaimana nabi bisa memperlihatkan etika yang baik sekaligus tegas saat berkomunikasi dengan orang badui, orang kafir quraisy, maupun dengan Raja.

\section{Etika Komunikasi Pemimpin Verbal Perpektif Hadits}

\section{a. Pengertian Komunikasi Verbal}

Komunikasi bergantung pada kemampuan untuk memahami satu sama lain. Meski ambigu namun tujuan utamanya adalah pemahaman. ${ }^{19}$ Menurut Agus M. Hardjana, komunikasi verbal adalah komunikasi yang menggunakan kata-kata, entah lisan maupun tertulis. Jika dalam dunia bisnis, komunikasi lisan lebih sering digunakan daripada komunikasi tertulis. Sama halnya dengan orang yang lebih suka mendengar daripada membaca. Hal ini terjadi karena lebih mudah, praktis, dan cepat. ${ }^{20}$ Jadi penting bagi pemimpin suatu perusahaan untuk menguasai etika komunikasi verbal. dengan baik. Bahkan E. Bruce Harrison dan Judith Mühlberg menekankan bahwa dalam demokrasi, eksekutif perusahaan harus memahami bahwa (1) keefektifan mereka menuntut mereka untuk menjadi komunikator yang sangat baik dan (2) mereka harus mengandalkan para ahli dalam komunikasi yang efektif (verbal, visual, tertulis, atau dalam orang) untuk membuat konten dan terhubung dengan pemangku kepentingan. ${ }^{21}$ Begitu pentingnya komunikasi dibangun sehingga seorang pemimpin perlu membentuk tim untuk menjadi staf ahli dalam menjalin komunikasi.

Komunakasi verbal merupakan komunikasi yang paling sering dipakai dalam hubungan antarmanusia karena mudah dalam mengungkapkan emosi, perasaan, gagasan, dan maksud secara langsung kepada lawan bicara. Sehingga lahir saling pengertian dan kemudahan dalam memahami

\footnotetext{
${ }^{19}$ Richard West dan Lynn H. Turner, Pengantar Teori Komunikasi, Edisi 3, Teori dan Aplikasi, Opcit hal. 3.

${ }^{20}$ Djoko Purwanto, Komunikasi Bisnis, (Erlangga:Jakarta, 2006), 6

${ }^{21}$ E. Bruce Harrison dan Judith Mühlberg, Leadership Communication: How Leaders Communicate and How Communicators Lead in Today's Global Enterprise, (New York: Business Expert Press, 2014) 28
} 
maksudnya lawan bicara. ${ }^{22}$ Dalam Islam sendiri, pesan verbal juga termaktub dalam bentuk lafzh, qaul, dan kalimah. ${ }^{23}$

Namun hadits nabi yang berbentuk verbal tersebut juga tak luput dari kontroversi. Menurut Muh. Syawir Dahlan, hal itu terjadi karena periwayatan hadits yang dilakukan banyak yang dimanfaatkan oknum sahabat demi kepentingan politiknya dengan menisbahkan kepada Nabi dan sahabatsahabatnya prasangka, fanatisme dan kejahilan mereka. Para ahli hadis menyebut berita imajiner ini sebagai hadis mawdhu'. Para penulisnya atau pengarangnya disebut alwadhdha atau al-kadzab (pendusta). Pada zaman Nabi, mereka disebut al-fasiq. Pada zaman sahabat, ada murid-murid sahabat yang terkenal pendusta. Di antaranya Ikrimah dan Muqatil bin Sulaiman. Ikrimah misalnya, banyak menisbahkan pendapatnya pada Ibnu Abbas. Ka'ab al-Ahbar banyak memasukkan mitos-mitos Yahudi dan Nasrani dalam tafsir, sehingga para ulama menyebutnya sebagai tafsir Isra'iliyat. ${ }^{24}$ Mengingat banyak hadits-hadits palsu yang dimanfaatkan oleh oknum tersebut, perlu ada kajian mendalam mengenai hadits tersebut dengan ditinjau dari rawi, sanad, maupun matannya untuk menyaring hadits-hadits tersebut.

\section{b. Hadits Tentang Etika Komunikasi Verbal Nabi Sebagai Pemimpin}

Sebagai seorang pemimpin, Nabi adalah pemegang otoritas keagamaan langsung dari Allah. Dalam Kitab Asy-Syamailul Muhamadiyyah karya Imam Turmudzi, dalam hal berbicara (komunikasi secara verbal), terdapat tiga hadis fi'liyah yang menjelaskan etika komunikasi verbal nabi: pertama, Tidak terlalu cepat, jelas, tegas, kedua Mengulang sampai faham, ketiga, Hanya berbicara perlu, mengawali dan mengakhiri dengan basmalah, dan tidak menghina. Menurut Muhammad Sulaiman dan Aizuddinnur Zakaria, dalam komunikasi verbal, Rasulullah menggunakan gaya komunikasi berupa pengulangan, berbicara jelas, dan tidak terburu-buru. ${ }^{25}$

\footnotetext{
22 Agus M. Hardjana, Komunikasi Intrapersonal dan Interpersonal, Opcit hal. 22

${ }^{23}$ Dodo Murtado, dkk. Manajemen dalam Perspektik Al Quran dan Hadits, (Bandung:Yrama Widya, 2019), 116120

${ }^{24}$ Muh. Syawir Dahlan, Etika Komunikasi Dalam Al-Qur'an dan Hadis, Jurnal Dakwah Tabligh, Vol .15, No. 1 (Makassar:UIN Alauddin Makassar, 2014), 120.

${ }_{25}$ Muhammad Sulaiman dan Aizuddinnur Zakaria, Jejak Bisnis Rasul terj. Gita Romadhona, (Jakarta:Mizan, 2010), 158
} 
1) Tidak terlalu cepat, jelas, tegas (Hadits dari Aisyah RA) ${ }^{26}$

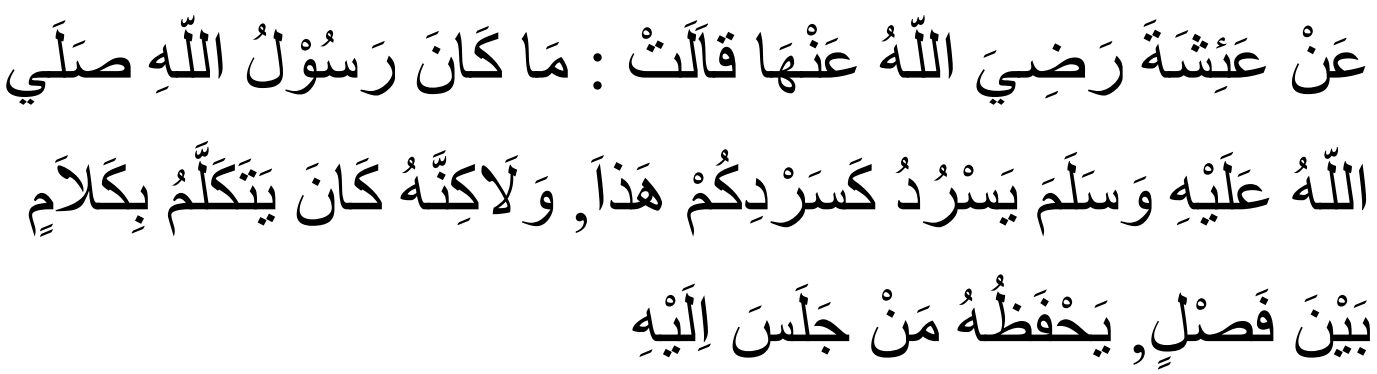

Artinya: "Dari Aisyah: Rasulullah SAW tidak berbicara cepat sebagaimana kalian. Tetapi beliau berbicara dengan kata-kata yang jelas dan tegas. Orang yang duduk bersamanya akan dapat menghafal (katakatanya)" (HR. Tirdmidzi)

Sanad hadits ini diriwayatkan dari Humaid bin Mas'adah al Basyriyyi dari Humaid al Aswad dari Usamah bin Zaid dari Zuhri dari Urwah yang bersumber dari Aisyah RA.

Hadits ini terdapat dalam Sunan Tirmidzi bab Manaqib, hadits no. $3643^{27}$ (dalam versi aplikasi haditssoft, hadits no. 3572 sedangkan cetakan penerbit Maktabah al Ma'arif Riyadl, hadits ini nomor 3639), terdapat pula dalam Shahih Bukhari dan Shahih Muslim. Juga terdapat pada sunan Abu Daud pada bab ilmu, hadits no. $3655 .^{28}$

Imam Tirmidzi menambahkan kedudukan hadits ini bersandarkan pada Abu Isa yang mengatakan "Hadits ini derajatnya hasan shahih, kami tidak mengetahuinya kecuali dari hadits Az Zuhri, Yunus bin Yazid juga telah meriwayatkan hadits ini dari Az Zuhri." Abu Thahir Zubair 'Ali Zai mengatakan hadits ini Shahih sedangkan M. Nashiruddin Al Albani mengatakan hadits ini Hasan.

\footnotetext{
${ }^{26}$ Imam at-Tirmidzi, Asyamailul Muhammadiyah (Pribadi dan Budi Pekerti Rasulullah SAW), terj. M. Tarsyi Hawi, (Bandung:CV Pernerbit Diponegoro, 1986), 173-176

${ }^{27}$ Imam at-Tirmidzi, Asyamailul Muhammadiyah (Pribadi dan Budi Pekerti Rasulullah SAW), Ibid. 173

${ }^{28}$ Imam at-Tirmidzi, Asyamailul Muhammadiyah (Pribadi dan Budi Pekerti Rasulullah SAW), Ibid. 173
} 
Hadits tersebut menjelaskan bagaimana Rasulullah berbicara dengan tidak terlalu cepat, jelas dan tegas. Tidak terlalu cepat berarti rasulullah menginginkan orang lain dapat mencerna isi perkataannnya. Jelas berarti berarti rasulullah berharap orang yang mendengarnya tidak salah mendengar, dan tegas membuktikan bagaimana rasulullah yakin dengan apa yang dikatakannya atau tidak ragu-ragu. Hal ini membuktikan bagaimana seorang pemimpin memberi arahan pada bawahannya. Kejelasan dalam komunikasi lisan tersebut, menurut Alo Liliweri, adalah kepadatan isi dan kelengkapan. Sehingga setiap pesan bisa tersampaikan dengan baik. Apalagi kata-kata tersebut bisa meminimalisir kesalahan dalam berkomunikasi. ${ }^{29}$

2) Mengulang sampai faham (Hadits dari Anas bin Malik RA)

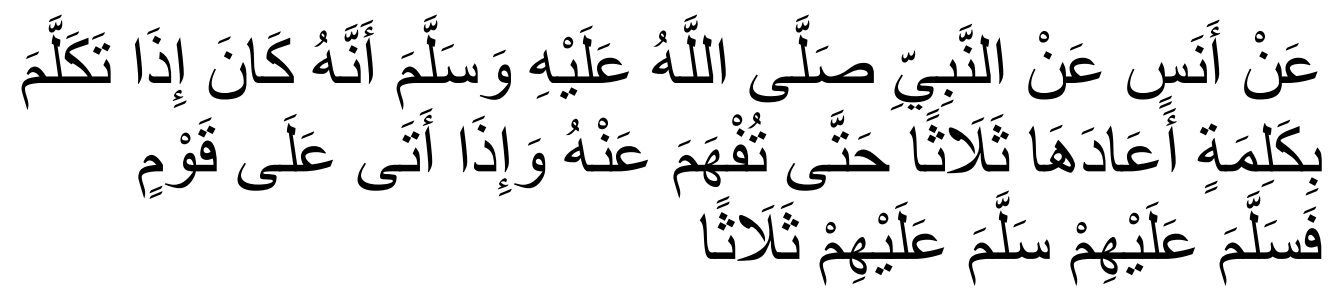

Artinya: "Telah menceritakan kepada kami 'Abdah bin Abdullah Ash Shafar Telah menceritakan kepada kami Abdushshamad berkata: Telah menceritakan kepada kami Abdullah bin Al Mutsanna berkata: Tsumamah bin Abdullah telah menceritakan kepada kami dari Anas dari Nabi shallallahu 'alaihi wa sallam, bahwa Nabi shallallahu 'alaihi wa sallam bila berbicara diulangnya tiga kali hingga dapat dipahami dan bila mendatangi kaum, Beliau memberi salam tiga kali." (HR. Bukhari, HR. Tirmidzi, HR. Ahmad)

Menurut versi Imam bukhari awal sanad hadits ini dari 'Abdah

bin Abdullah Ash Shafar kepada Abdushshamad kepada Abdullah bin Al Mutsanna kepada Tsumamah bin Abdullah kepada ujung sanad yaitu Anas bin Malik RA sedangkan pada musnad Ahmad langsung pada Abdushshamad hingga ujung sanad. Menurut imam tirmidzi, sanad hadits ini diriwayatkan oleh Muhammad bin Yahya dari Abu Qutaibah (Muslim bin Qutaibah) dari Abdullah bin al Mutsani dari Tsumamah yang bersumber dari Anas bin Malik RA.

Hadits ini terdapat pada dalam Shahih Bukhari bab Ilmu dan Idzin dengan nomor 93 (pada kitab Fathul Bari no. 95). Sunan Tirmidzi bab

${ }^{29}$ Alo Liliweri, Komunikasi Serba ada Serba Makna, Opcit, 378. 
Manaqib hadits no. 3644 (dalam versi aplikasi haditsSoft no. 3573 sedangkan pada cetakan penerbit Maktabah al Ma'arif Riyadl hadits ini nomor 3640), juga pada bab Idzin hadits no. 2724 (dalam versi aplikasi haditsSoft no. 3647 sedangkan pada cetakan penerbit Maktabah al Ma'arif Riyadl hadits ini nomor 2723). Lalu pada Musnad Ahmad hadits ini terletak pada no. 12744 (dalam versi penerbit Muasasah Ar Risalah no. 13221).

Mengenai kedudukan hadits ini, Imam Tirmidzi menuliskan bahwa Abu Isa berkata: "Hadits ini derajatnya hasan shahih gharib, kami hanya mengetahuinya dari hadits Abdullah bin Al Mutsanna." Abu Thahir Zubair 'Ali Zai mengatakan hadits ini Shahih sedangkan M. Nashiruddin Al Albani mengatakan hadits ini Hasan Shahih. Sedangkan dalam Musnad Ahmad, Syu'aib Al Arnauth mengatakan bahwa sanad hadits ini hasan.

Dari hadits tirdmidzi tersebut, nabi mengulang hingga tiga kali. Hal itu menjadi cerminan bagaimana seorang pemimpin memberi arahan pada bawahan dengan sabar mengulang perintah atau arahan hingga dimengerti. Terutama pada arahan yang penting dan berhubungan dengan tugas yang akan dikerjakan. Hal itu perlu dilakukan untuk mengurangi resiko kesalahan dalam melakukan pekerjaan. Namun, meski demikian terdapat tambahan etika mengenai menyampaikan tiga kali ini dalam versi Imam Bukhari dengan mengucapkan salam terlebih dahulu:

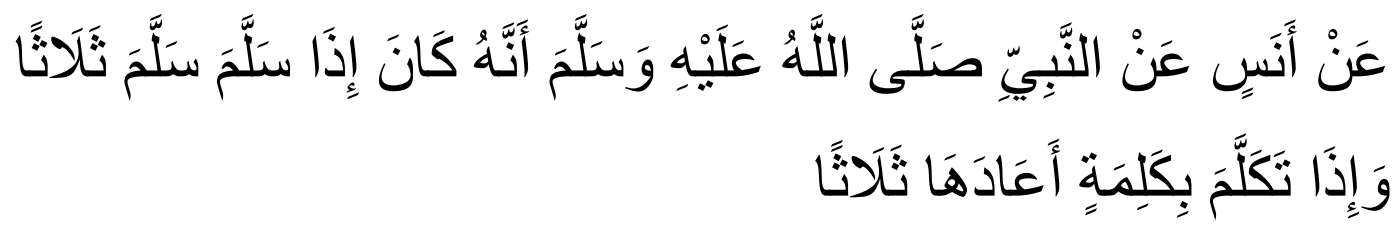

Artinya: "Dari Anas dari Nabi shallallahu 'alaihi wa sallam, bahwa Nabi shallallahu 'alaihi wa sallam apabila memberi salam, diucapkannya tiga kali dan bila berbicara dengan satu kalimat diulangnya tiga kali." (HR Bukhari no. 92, 5775)

Sanad hadist tersebut dari Abdah berkata lalu

pada Abdushshamad kepada Abdullah bin Al Mutsanna berlanjut kepada Tsumamah bin Abdullah dan berujung pada Anas bin Malik RA

Cara bicara tiga kali tersebut ditambah dengan etika nabi dalam meminta ijin terlebih dahulu. Hal itu tertuang dalam hadits riwayat ahmad: 


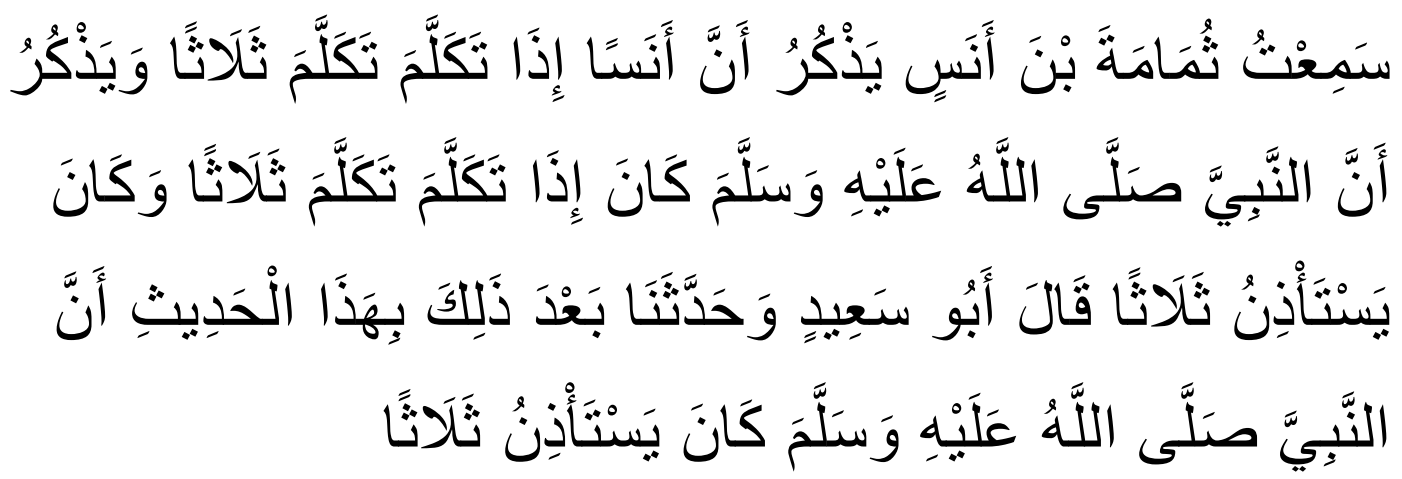

Artinya: "Saya telah mendengar Tsumamah bin Anas menyebutkan, Anasjika berbicara ia mengulanginya tiga kali dan mengingatkan, Nabi shallallahu 'alaihi wa sallam jika berbicara (mengulanginya) tiga kali dan jika meminta ijin mengulanginya tiga kali. Abu Sa'id berkata: dan telah menceritakan kepada kami setelah itu dengan hadis ini, sesungguhnya Nabi shallallahu 'alaihi wa sallam jika meminta ijin mengulanginya tiga kali." (HR. Ahmad 12830 dan 12744)

Sanad hadits tersebut dari Abu Said, budak Bani Hasyim telah menceritakan kepadanya Abdullah bin al-Mutsanna dan berujung pada Tsumamah bin Anas.

Dalam hadits tersebut disebutkan bagamana nabi meminta izin terlebih dahulu. Permintaan izin tersebut bukan karena nabi meremehkan daya tangkap atau pendengaran para sahabat, namun lebih ke etika bagaimana nabi menghormati dan menghargai para sahabat yang ingin bertanya namun sungkan, atau sahabat yang berada dibelakang dan tidak mendengarkan arahan nabi. Dengan meminta ijin tersebut, nabi menghormati orang yang di barisan depan yang sudah jelas mendengar, dan menghargai sahabat yang di barisan belakang yang tidak mendengar terlalu jelas.

3) Hanya berbicara perlu, mengawali dan mengakhiri dengan basmalah, dan tidak menghina (Hadits dari Hasan bin Ali RA)

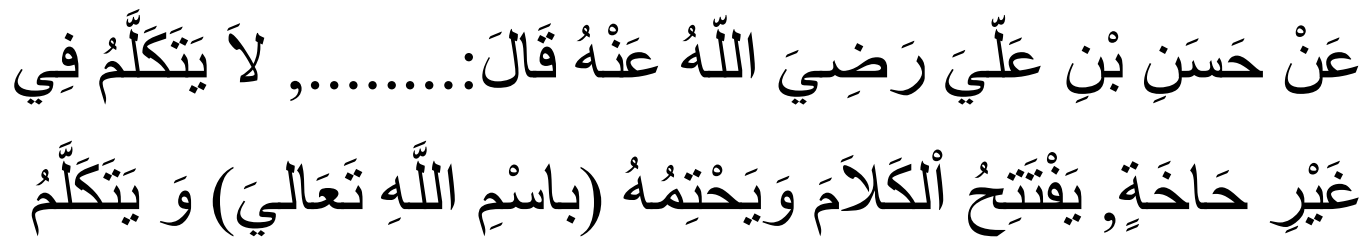




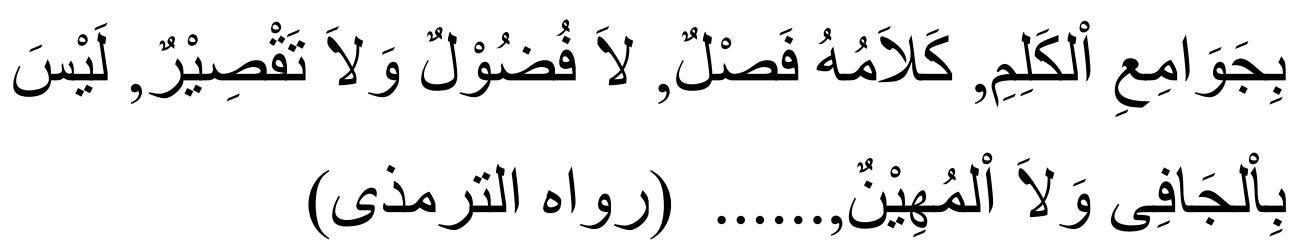

Artinya: "Dari Hasan bin Ali RA: Aku bertanya pada pamanku Hind bin Abu Hallah $^{30}$.....Rasulullah SAW tiada berbicara kecuali apabila perlu. Membuka dan menutup pembicaraannya dengan menyebut nama Allah SWT. Isi pembicaraannya pada dengan makna, kata-katanya jelas, tiada yang sia-sia dan tiada pula yang kurang dipahami. Beliau tidak pernah berlaku kasar dan tiada pernah menghina...." (HR. Tirmidzi)

Sanad hadits ini diriwayatkan oleh Sufyan bin Waki'dari Juma'i bin Umar bin Abdurrahman al Ijli, dari seorang laki-laki Bani Tamim yang katanya dari putra Abu Hallah (suami Khadijah Ummul Mukminin sebelum menjadi istri Rasulullah SAW,) yakni Abu Abdillah yang bersumber dari Hasan bin Ali KW. ${ }^{31}$

Berdasarkan hadits tersebut, dapat kita simpulkan bahwa ada tiga etika penting bagi seorang pemimpin dalam memberi arahan pada bawahannya, yaitu:

1) hanya berbicara bila perlu, hal ini penting untuk menjaga wibawa dengan bawahan dan relasi.

2) Mengawali dan mengakhiri dengan basmalah, untuk menata niat dan mengharap ridha Allah

3) Tidak menghina, yaitu tidak memberi ujaran kebencian (hate speech) untuk menjaga hubungan dengan orang lain.

Dalam berorganisasi dan berlembaga, komunikasi merupakan hal yang penting. Jika terhambat maka organisasi tidak bisa berjalan lanjar. Robbins dkk, mengungkapkan bahwa ada beberapa hambatan komunikasi dalam organisasi, yaitu: filtering (penyaringan), selective perception (persepsi selektif), information overload (informasi yang berlebihan), emotions (emosi), language (Bahasa), silence (keheningan), nonverbal

\footnotetext{
${ }^{30}$ Hind bin Abu Hallah adalah saudara seibu Fatimah binti Rasulullah SAW. Ia adalah anak Khadijah RA dari suaminya yang terdahulu yang bernama Abu Halah. Hind. Wafat pada waktu Waqi'atul Jamal di pihak Ali bin Abi Thalib KW.

${ }^{31}$ Imam at-Tirmidzi, Asyamailul Muhammadiyah (Pribadi dan Budi Pekerti Rasulullah SAW), Ibid, hal 175
} 
communication (komunikasi nonverbal), lying (berbohong). ${ }^{32}$ Kesemua hambatan organisasi itu bisa ditanggulangi oleh pemimpin dengan menggunakan komunikasi verbal yang baik. Wayan Gede Supartha dan Desak Ketut Sintaasih memberikan solusi berupa komunikasi jaringan yang efektif, yaitu (1) Meningkatkan umpan balik, (2) Empati, (3) Pengulangan, (4) Menggunakan bahasa yang sederhana, (5) Penentuan waktu yang efektif, (6) Mendengarkan secara efektif, (7) Mengatur arus informasi. ${ }^{33}$ Dalam Wayan Gede Supartha dan Desak Ketut, terdapat solusi yang harus diperhatikan sesuai dengan jaman sekarang, yaitu mengatur arus informasi. Penting bagi pemimpin membuat atau bergabung dengan grup sosial media yang didalamnya terdapat bawahannya. Menurut Robbins, hal itu perlu untuk mengatur arus informasi juga dalam memonitar pegawai ${ }^{34}$. Namun tetap etika pemimpin menurut nabi perlu diterapkan, sebagaimana dalam hadits:

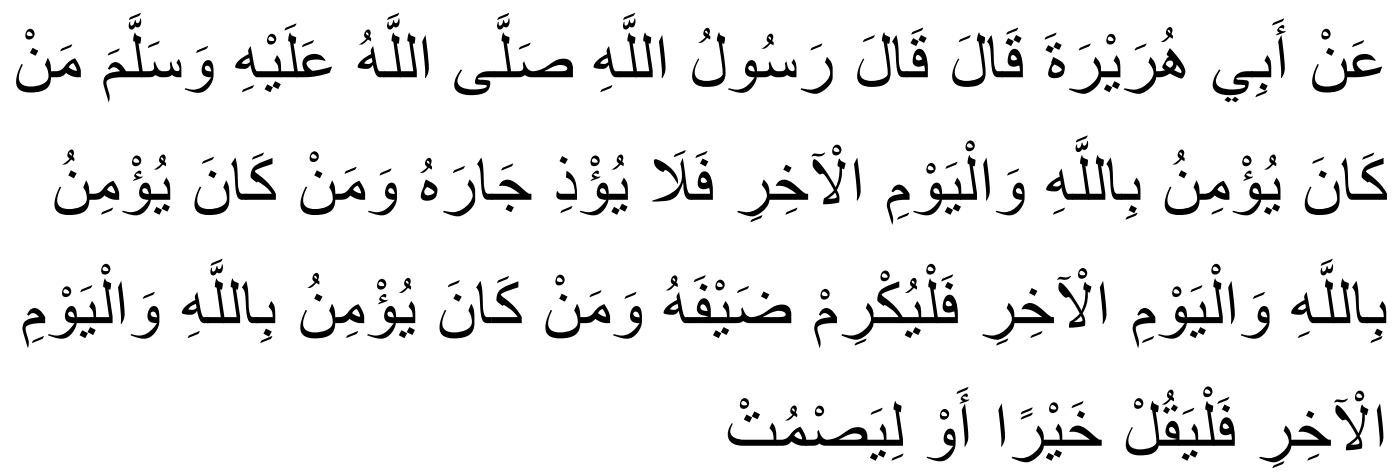

Artinya: Dari Abu Hurairah dia berkata: Rasulullah shallallahu 'alaihi wa sallam bersabda: "Barangsiapa berimana kepada Allah dan hari Akhir, janganlah ia mengganggu tetangganya, barangsiapa beriman kepada Allah dan hari Akhir hendaknya ia memuliakan tamunya dan barangsiapa beriman kepada Allah dan hari Akhir hendaknya ia berkata baik atau diam." (HR Bukhari, HR Muslim, HR. Tirmidzi, HR. Ibnu Majah, HR. Ahmad)

\footnotetext{
32 Stephen P Robbins, Nancy Langton , Timothy A. Judge, Organizational behavior Concepts, Controversies, Applications Seventh Edition, (Toronto, Pearson, 2016), 251-255.

${ }^{33}$ Wayan Gede Supartha dan Desak Ketut Sintaasih, Pengantar Perilaku Organisasi Teori, Kasus, dan Aplikasi Penelitian (Denpasar:CV Setia Bakti, 2017), 87-88.

${ }^{34}$ Stephen P Robbins, Nancy Langton, Timothy A. Judge, Organizational behavior Concepts, Controversies, Applications, Ibid, 268.
} 
Dalam shahih bukhari, hadits ini sanadnya mulai Qutaibah bin Sa'id telah menceritakan kepada Abu Al Ahwash dari Abu Hashin dari Abu Shalih dari Abu Hurairah.

Hadits tersebut terdapat pada Shahih Bukhari 5559, 5670, 5671, 5673, pada bab adab, dan no. 5994 pada Bab hal-hal yang melunakkan hati. Pada Shahih Muslim no. 67, 68, 69 pada Bab Iman dan 3255 pada Bab Barang Temuan. Pada Abu Daud terdapat pada no. 4487 Bab Adab. Pada Sunan Tirmidzi no. 1890 pada Bab Berbakti dan Menyambung Silaturahmi dan no. 2424 pada Bab Sifat Kiamat, Penggugah Hati, dan Wara'. Pada Sunan Ibnu Majah no. 3662 pada Bab Adab dan no. 3961 pada Bab Fitnah. Pada Musnad Ahmad disebutkan 10 kali (no. 6332, 7307, 9223, 9588, 9591, 15775, 19403, 22398, 23268, 25906). Dalam Sunan Darimi terdapat pada no. 1949 pada Bab Makanan.

Begitu pentingnya Nabi menjaga komunikasi verbal sehingga meminta kepada umatnya untuk diam jika memang tidak mengkomunikasikan sesuatu dengan baik. Terkait hadits di atas, Ninik Handrini memaparkan bahwa dalam hal berkomunikasi, nabi menghindari tiga perkara, yaitu berdebat, berlebihan dalam harta maupun bicara, dan ikut campur dalam perkara atau pembicaraan yang bukan urusannya. ${ }^{35}$ Dalam syarah Arbain Nawawi disebutkan, nabi menyatakan dengan menggunakan lam amr (lam yang bermakna perintah, fal yakul) untuk mengucapkan kata-kata yang baik atau untuk diam. Diantara bentuk perkataan baik itu adalah menyampaikan ajaran Allah dan Rasul-Nya, memberikan pengajaran kepada kaum muslimin, memerintahkan yang makruf berdasarkan ilmu dan mengingkari kemungkaran berdasarkan ilmu, mendamaikan orang yang berselisih, dan mengucapkan kata-kata yang baik kepada orang lain. Di antara kata-kata yang paling utama adalah kata-kata kebenaran dengan penuh dengan keteguhan di hadapan orang yang ditakuti kekejamannya yang diharap kebaikannya. ${ }^{36}$

\section{Etika Komunikasi Nonverbal Perspektif Hadits}

\footnotetext{
${ }^{35}$ Ninik Handrini. Berkata Baik atau Diam 294 Adab Kebiasaan Rasulullah SAW, (Jakarta:Gramedia, 2016), .xxii

${ }^{36}$ Ibnu Daqiq, Al-Id, Syarah Hadits Arba'in, (Sukoharjo: Pustaka Arafah, 2007), 195
} 


\section{a. Pengertian Komunikasi Nonverbal}

Menurut Agus M. Hardjana, komunikasi nonverbal adalah komunikasi yang pesannya dikemas dalam bentuk nonverbal, tanpa kata-kata. Dalam kenyataannya, komunikasi nonverbal ternyata jauh lebih banyak diakai daripada komunikasi verbal. Dalam berkomunikasi, hampir secara otomatis komunikasi nonverbal juga ikut terpakai. Komunikasi nonverbal lebih jujur daripada komunikasi verbal karena diungkapkan secara spontan dan tanpa disadari. Meskipun begitu, komunikasi nonverbal lebih sulit ditafsiri karena tidak diungkapkan. Agus M. Hardjana mencontohkan orang yang berjabat tangan mungkin masih sulit dimengerti. Tetapi jika disambung dengan raut wajah seperti cemberut, gerak mata seperti terkejut, atau gerak tubuh lain yang tegang, maka kita bisa lebih sulit lagi mengartikannya. Butuh pengalaman dan kepekaan yang lebih tinggi dalam menafsirkan komunikasi nonverbal. A. Andhita sari lebih jauh memaparkan sembilan perilaku nonvebal, yaitu kinetik(gerak tubuh), haptik (sentuhan), penampilan fisik, artefak (obyek), proksemis (jarak dalam ruang), faktor lingkungan, kronemis (waktu), parabahasa (gumaman, nafas, dan lainnya). ${ }^{37}$ Kesembilan tanda itu secara sadar maupun tidak sadar melekat pada manusia. Tak terkecuali seorang pemimpin.

Bagi seorang pemimpin, penting untuk berkomunikasi yang baik dengan bawahan. Baldoni menyarankan agar setiap pemimpin organisasi tidak hanya berkomunikasi dengan menggunakan kata-kata, tetapi juga dengan perilaku rutin mereka. Perilaku yang terlibat membawa sejuta makna yang jauh lebih dalam daripada sekedar perintah kata-kata. Inilah kepemimpinan yang sejati, dan bukan sekedar bos, apalagi birokrat. Mereka terlibat di dalam semua dimensi kerja organisasinya. Dengan itu cinta mereka terhadap apa yang mereka kerjakan memancar keluar, dan menular ke komunitas sekitarnya. ${ }^{38}$ Untuk itu perlu bagi seorang pemimpin memperhatikan perilaku nonverbalnya sebagai bagian dari etika komunikasi agar tidak terjadi salah paham dalam mengarahkan bawahannya.

\footnotetext{
37 A. Anditha Sari, Komunikasi Antarpribadi, (Sleman:DeePublish, 2017), 46

${ }^{38}$ Dalam Reza A. A. Wattimena, Menjadi Pemimpin Sejati Sebuah Refleksi Lintas Ilmu (Jakarta, PT Evolitera, 2012), 105
} 


\section{b. Hadits Tentang Etika Komunikasi Nonverbal Nabi Sebagai Pemimpin}

Agus M. Hardjana membagi bentuk komunikasi nonverbal dalam empat bentuk, yaitu: (1) Bahasa tubuh (body language), berupa raut wajah, gerak kepala gerak tangan, gerak-gerik tubuh mengungkapkan berbagai perasaaan, isi hati, isi pikiran, kehendak, dan sikap orang. (2) Tanda (sign), berupa pengganti kata, dan bisa melalui media seperti bendera, rambu lalu lintas, aba-aba dalam olah raga, dan lainnya. (3) Tindakan/perbuatan (action), meskipun bukan untuk mengganti kata, namun dapat menghantarkan makna. Seperti menggebrak meja, menutup pintu keras-keras pada saat meninggalkan ruangan, dan sebagainya. (4) Objek (object), sebagai bentuk komunikasi nonverbal juga tidak mengganti kata, tetapi dapat menyampaikan arti tertentu. Misalnya, pakaian, aksesori dandan, rumah, kendaraan, hadiah, dan lainnya.

Berdasarkan pembagian tersebut, maka etika komunikasi pemimpin berdasarkan komunikasi nonverbal dalam perspektif hadits adalah:

\section{1) Hadist mengenai Bahasa tubuh}

Banyak hadits yang menerangkan mengenai bahasa tubuh Nabi yang digunakan untuk mengungkapkan perasaan dan sikap nabi. Mengenai hal ini terdapat dua hadis yang berkaitan tentang etika nabi sebagai seorang pemimpin, yaitu mengenai cara nabi duduk dan etika ketika nabi memperoleh wahyu

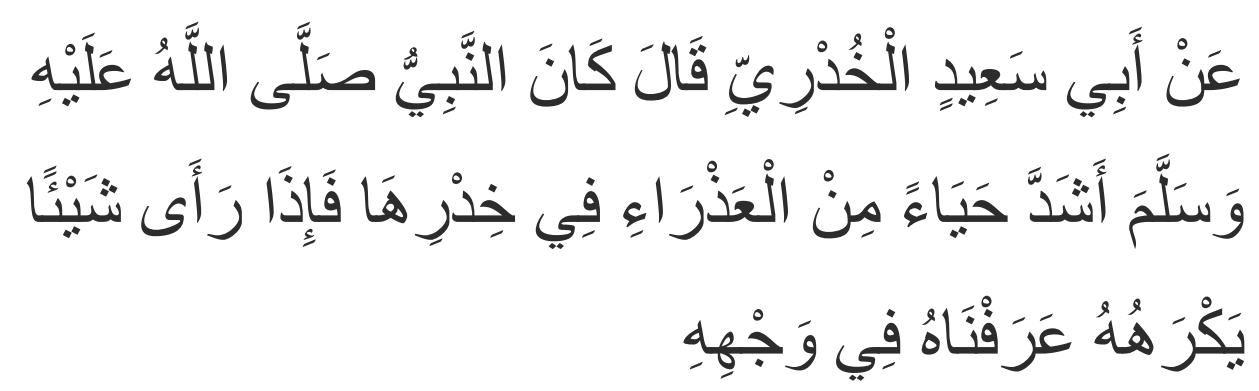

Artinya: "Dari Abu Sa'id Al Khudri dia berkata: Nabi shallallahu 'alaihi wa sallam adalah sosok yang lebih pemalu daripada seorang gadis yang dipingit dalam rumah, apabila beliau melihat sesuatu yang tidak disukainya, maka kami akan mengetahui dari raut muka beliau." (HR. Bukhari, HR. Ahmad)

Menurut Versi Imam Bukhari sanad hadits ini dari Abdan telah

kepada Abdullah kepada Syu'bah dari Qatadah dari Abdullah (Ibnu Abu 'Utbah bekas budak Anas), dari Abu Sa'id Al Khudri. Sedangkan dalam 
versi Imam Ahmad, sanad hadits ini dari Bahz kepada Syu'bah kepada kami Qotadah dari Abdullah bin Abu Utbah dari Abu Sa'id Al Khudri.

Dalam versi Shahih Bukhari, Hadits ini ada pada no. 5637 sedangkan pada kitab Fathul Bari pada no. 6102) pada Kitab Adab pada bab tidak menghadapi manusia dengan cercaan sedangkan dalam Musnad Ahmad no. 11258 (dalam versi cetakan penerbit Muasasah Ar Risalah no. 11683) pada bab Musnad Abu Said al Khudri RA. Semua ulama sepakat mengenai keshahihannya.

Hadits tersebut menjelaskan bahwa para sahabat sangat mengenal cara rasulullah berkomunikasi nonverbal melalui raut mukanya. Jika rasulullah tidak suka, maka sahabat akan tahu melalui raut mukanya tanpa rasul mengatakan tidak suka. Raut muka adalah salah satu komunikasi nonverbal yang paling mudah dibaca oleh para komunikan. A. Anditha Sari memaparkan bahwa dengan raut muka juga bisa mengungkapkan berbagai perasaan, isi hati, isi pikiran, kehendak, dan sikap orang. ${ }^{39}$ Dalam hadits tersebut, raut muka nabi berubah dan para sahabat menyadarinya. Baik itu berubah mimiknya maupun warnanya. Sasa Djuarsa Sendjaja, dkk mengkategorikan perubahan raut wajah dalam bentuk kinesics, yaitu ekspresi wajah yang berubah tanpa melihat apakah kita sedang sedang berbicara atau mendengarkan. ${ }^{40}$ Seperti yang dituliskan Henry H. Calero; No other part of the body reacts more dramatically to a flow of blood than the face. ${ }^{41}$ Tidak ada bagian tubuh yang bereaksi lebih dramatis terhadap aliran darah selain wajah. Jadi bentuk komunikasi nabi melalui raut muka sangat manusiawi dan berlangsung baik dalam keadaan sadar maupun tidak sadar bahwa raut muka nabi berubah dengan sendirinya, baik dengan bawahan, maupun dengan atasan pemimpin/manejer tersebut. Mengenai etika berkomunikasi dengan atasan, nabi mencontohkan dalam haditsnya:

\footnotetext{
${ }^{39}$ A. Anditha Sari, Komunikasi Antarpribadi, Opcit, 45

${ }^{40}$ Sasa Djuarsa Sendjaja, dkk., Teori Komunikasi (Tangerang:Universitas Terbuka, 2014), 6.17.

${ }^{41}$ Henry H. Calero, The Power of Nonverbal Communication How You Act Is More Important Than What You Say, (Aberdeen: Silver Lake Publishing, 2015), 73
} 


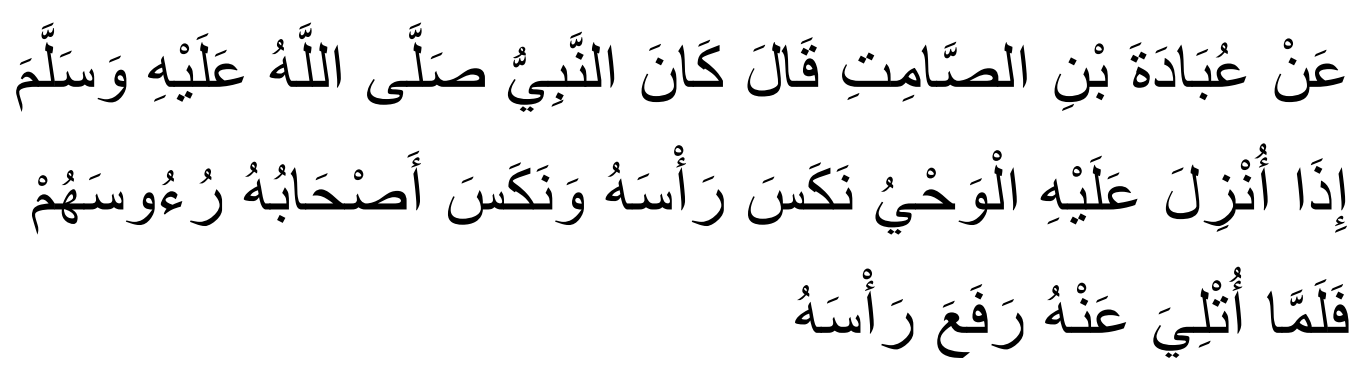

Artinya: "Dari 'Ubadah bin Ash Shamit "Apabila wahyu sedang turun kepada Nabi shallallahu 'alaihi wa sallam, beliau menundukkan kepalanya, dan para sahabat pun ikut menundukkan kepala. Dan apabila wahyu telah selesai di bacakan, beliau mengangkat kepala kembali." (HR. Muslim No. 4306)

Hadits ini diriwayatkan oleh Muhammad bin Basysyar: Telah menceritakan kepada kami Mu'adz bin Hisyam: Telah menceritakan kepada kami Bapakku dari Qatadah dari Al Hasan dari Hiththan bin 'Abdillah Ar Raqasyi dari 'Ubadah bin Ash Shamit.

Dalam Syarah Sahih Muslim, hadits ini menepati no. 2335 sedangkan dalam aplikasi web https://gethadith.web.app/ menempati no. 4306. Ulama sepakat untuk menempatkan hadits ini sebagai hadits shahih. 42

Begitu juga pada saat nabi menerima wahyu, nabi menunduk. Hal itu menunjukan bahwa sebagai pemimpin yang memiliki atasan (kepala sekolah terhadap Menteri Pendidikan, kepala KUA terhadap Menteri agama, dan lainnya) haruslah tetap menjaga etika, yaitu itu dengan menundukkan kepala. Hal itu menunjukkan sikap taat dan patuh.

\section{2) Hadits mengenai tanda}

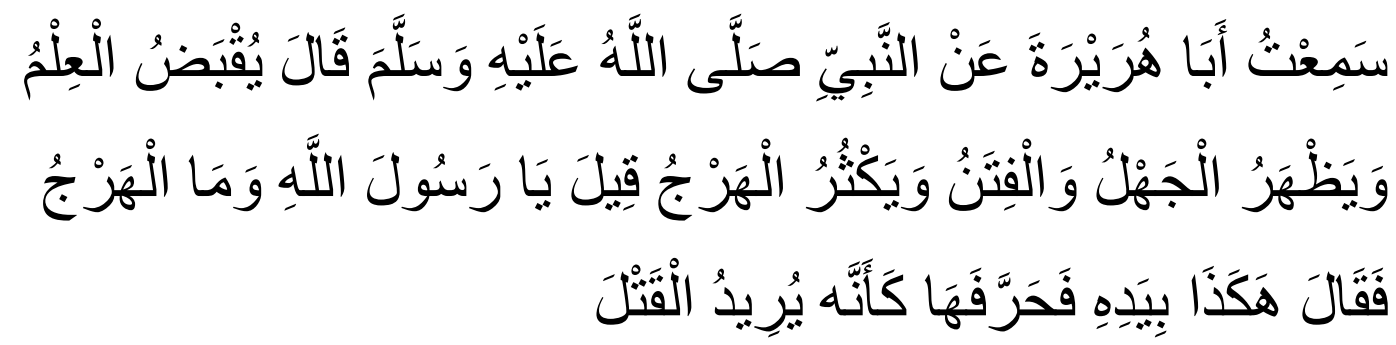

Artinya: "Aku mendengar Abu Hurairah dari Nabi shallallahu 'alaihi wa sallam, beliau bersabda: "Ilmu akan diangkat dan akan tersebar kebodohan dan fitnah merajalela serta banyak timbul kekacauan." Ditanyakan kepada Beliau: "Wahai Rasulullah, apa yang dimaksud

${ }^{42}$ Penomeran menurut Syarh Shahih Muslim karya Imam An Nawawi, cetakan Daarul Hadits Kairo 
dengan kekacauan?" Maka Rasul shallallahu 'alaihi wa sallam menjawab: "Begini." Nabi shallallahu 'alaihi wa sallam memberi isyarat dengan tangannya lalu memiringkannya. Seakan yang dimaksudnya adalah pembunuhan." (HR. Bukhari)

Hadits ini diriwayatkan melalui sanad Al Makki bin Ibrahim berkata: telah mengabarkan kepada kami Hanzhalah bin Abu Sufyan dari Salim kepada Abu Hurairah.

Berdasarkan aplikasi web https://gethadith.web.app/,, hadits ini terdapat pada bab Ilmu dengan no. hadits 83 (dalam Fathul Bari urutan no. 85), dan ijma' Ulama sepakat mengenai keshahihannya.

Hadits ini menunjukkan bagaimana Rasulullah menggunakan tangannya sebagai tanda agar para sahabat mengerti. Menggunakan tanda merupakan Bahasa nonverbal agar komunikan bisa lebih cepat faham tanpa menjelaskan berlama-lama. Komunikasi melalui tanda dan symbol atau Calero menggunakan istilah semiotic. Ia menambahkan jika seseorang hendak membuat pengungkapan yang tulus, kedua tangan itu biasanya di atas meja dan pembicara akan memberi isyarat dengan mereka ketika dia berbicara. ${ }^{43}$ Jadi apa gestur tangan yang digunakan oleh nabi dalam hadits tersebut menunjukkan ketulusan beliau dalam berkomunikasi dengan komunikan. Fungsi pesan lain dalam gerakan tangan pada saat komunikasi berlangsung seperti pada hadits tersebut adalah menegaskan atau menjelaskan apa yang dikatakan, memberi penekanan pada pembicaraan dan mengilustrasikan apa yang sedang dikatakan. ${ }^{44}$ Jadi penggunaan tangan untuk menggantikan kata "pembunuhan" adalah bentuk penegasan, sekaligus penjelasan.

\section{3) Hadits mengenai tindakan/perbuatan}

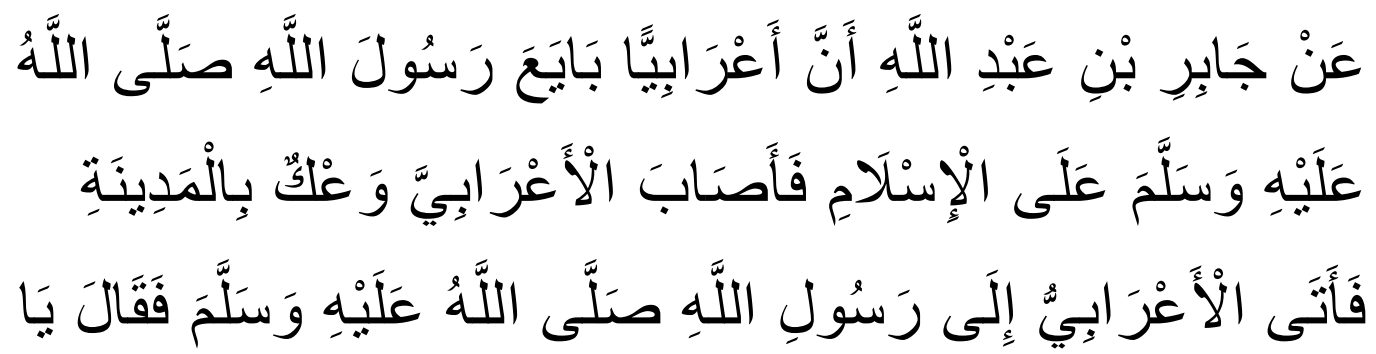

\footnotetext{
${ }^{43}$ Henry H. Calero, The Power of Nonverbal Communication, opcit, 85

${ }^{44}$ Sasa Djuarsa Sendjaja, dkk., Teori Komunikasi,Opcit. 6.18.
} 


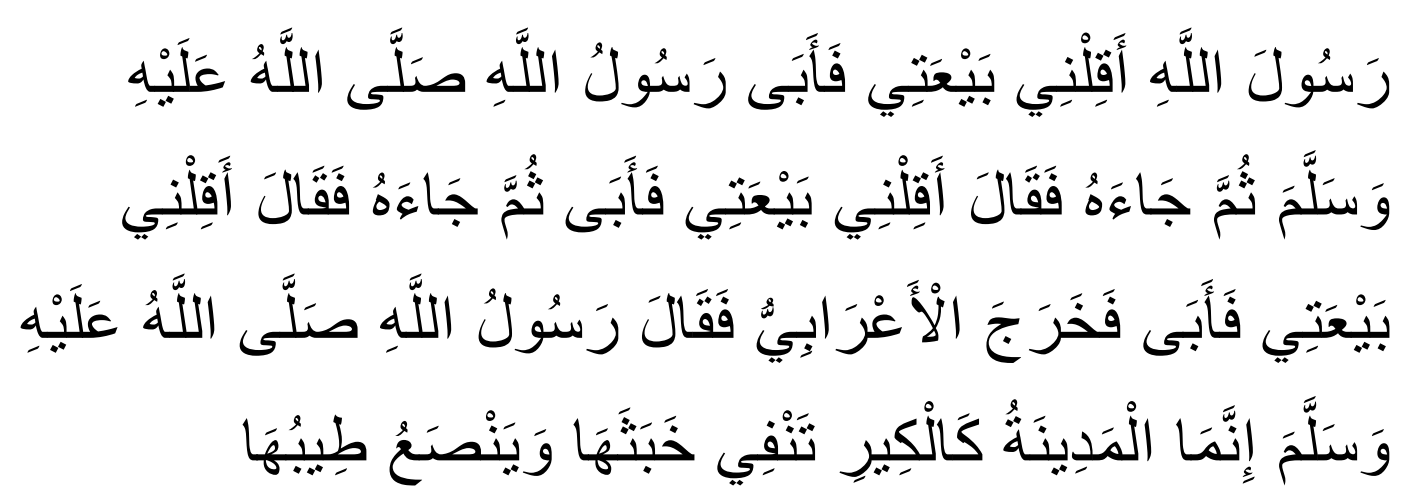

Artinya: "Dari Jabir bin Abdillah mengatakan: 'Seorang arab badui (nomade) mendatangi Nabi shallallahu 'alaihi wa sallam dan berujar "Baiatlah aku untuk Islam, " maka Nabi membaiatnya untuk Islam. Keesokan harinya si arab badui tadi datang dalam keadaan demam, dan berujar: "batalkanlah baiatku" namun Nabi enggan. Ketika si arab badui sudah berpaling, Nabi bersabda: "Madinah ini bagaikan tungku api yang menghilangkan karat-karatnya dan menyaring yang baik saja. (HR. Bukhari, HR. Ahmad, HR. Malik)

Sanad hadits ini adalah Abu Nu'aim telah menceritakan kepada Sufyan dari Muhammad bin Al Munkadir, dari Jabir bin Abdillah.

Berdasarkan aplikasi web https://gethadith.web.app/ hadits tersebut disebutkan tiga kali pada shahih bukhari $(6671,6676,6669)$, tiga kali pada Musnad Ahmad (13781, 13766, 14409), dan sekali pada Muwatha' Malik (1377). Ulama juga sepakat mengenai kedudukan hadits ini dalam tingkatan shahih.

Dari apa yang disebutkan dalam hadits, nabi memberi contoh pada kita bagaimana nabi bersikap tegas pada orang-orang yang mencoba menghina dalam hal agama. Keengganan nabi merupakan suatu aksi untuk menunjukkan ekspresi ketidaksukaannya. Joe Navarro menuliskan bahwa sikap adalah sebuah komunikasi nonverbal. ${ }^{45}$ Keengganan yang dilakukan nabi juga terlihat dari bagaimana nabi mengatur jarak hingga orang badui tersebut berpaling. Sasa Djuarsa Sendjaja, dkk., mengkategorikan hal tersebut sebagai proxemics, yaitu suatu cara bagaimana orang-orang yang terlibat dalam suatu tindak komunikasi berusaha untuk merasakan dan menggunakan ruang. ${ }^{46}$ Bentuk diam yang dilakukan nabi termasuk dalam paparan Calero, yaitu diam adalah pilihan batin, keputusan untuk menahan

\footnotetext{
45 Joe Navarro, Cara Cepat Membaca Bahasa Tubuh, (Change Publications, 2014), 134

${ }^{46}$ Sasa Djuarsa Sendjaja, dkk., Teori Komunikasi Opcit. 6.18
} 
pernyataan atau ekspresi di bawah kerahasiaan keyakinan pribadi, spiritual, agama, politik, atau lainnya. ${ }^{47}$ Jadi keengganan dalam diam merupakan suatu yang personal dan merupakan kebebasan dalam bereskpresi.

\section{4) Hadits mengenai obyek}

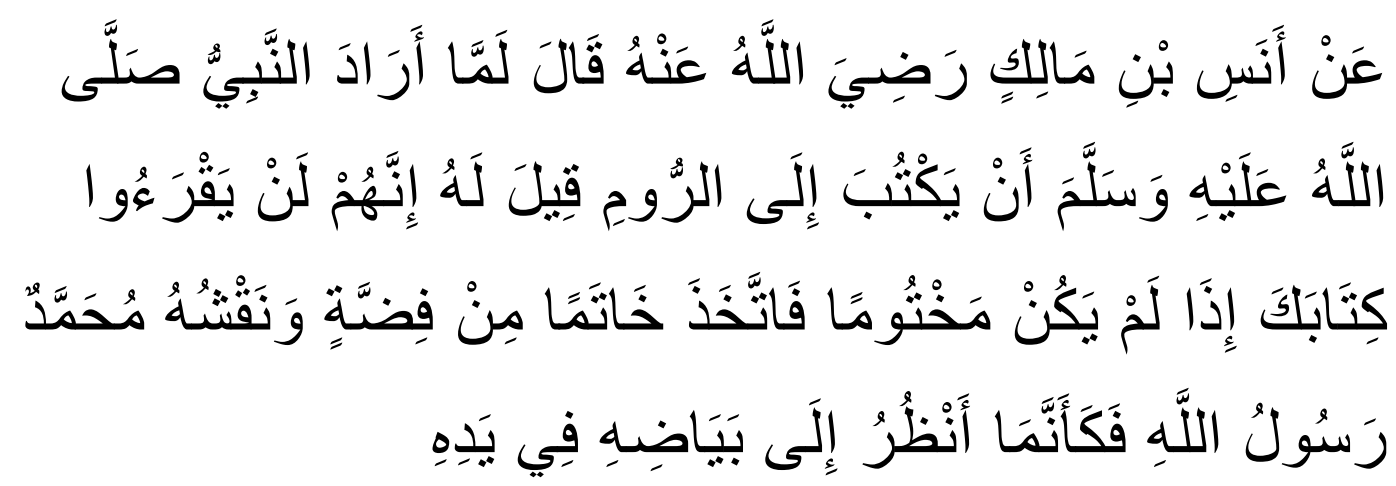

Artinya:"Telah menceritakan kepada kami Adam bin Abu Iyas telah menceritakan kepada kami Syu'bah dari Qatadah dari Anas bin Malik radliallahu 'anhu dia berkata: "Ketika Nabi shallallahu 'alaihi wa sallam hendak menulis surat ke raja Romawi, maka diberitahukan kepada beliau: 'Sesungguhnya mereka tidak akan mau membaca surat anda karena tidak ada stempel.' Setelah itu beliau membuat cincin (stempel) yang terbuat dari perak dan mengukirnya dengan tulisan 'Muhammad Rasulullah' seakan-akan saya melihat putihnya (cahaya) dari tangan beliau." (HR. Bukhari, HR. Muslim, HR. Abu Daud, dan HR. Ahmad)

Sanad hadits ini melalui empat versi, yaitu Bukhari, Muslim, Abu Daud, dan Imam Ahmad. Perbandingan sanad pada hadits ini untuk lebih mudahnya pada tabel berikut:

\begin{tabular}{|l|l|l|l|}
\hline Bukhari & Muslim & Abu Daud & Ahmad \\
\hline - Anas bin Malik & - Anas bin Malik & - Anas bin Malik & - Anas bin Malik \\
- Qatadah bin & - Qatadah bin & - Qatadah bin & - Qatadah bin \\
Da'amah & Da'amah & Da'amah & Da'amah \\
- Syu'bah bin Al & - Syu'bah bin Al & - Sa'id bin Abi & - Syu'bah bin Al \\
Hajjaj & Hajjaj & 'Urubah Mihran & Hajjaj dan \\
- Adam bin Abu & - Muhammad bin & - Isa bin Yunus & Hajjaj bin \\
Iyas & Ja'far & bin Abi Ishaq & Muhammad \\
& - Muhammad bin & - Abdur Rahim & Muhammad \\
& Al Mutsannaa dan & bin Mutharrif & bin Ja'far \\
& \multicolumn{2}{|l}{ bin Unais } & \\
\hline
\end{tabular}

${ }^{47}$ Henry H. Calero, The Power of Nonverbal Communication, opcit, 61 


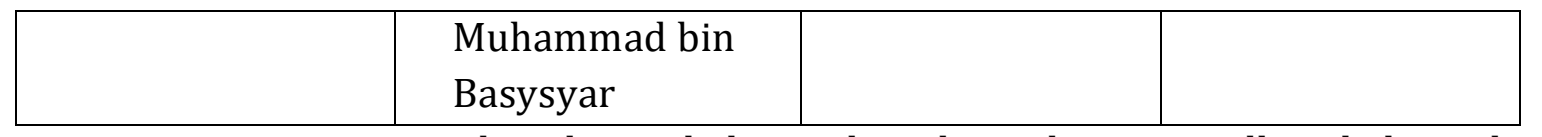

Berdasarkan tabel tersebut dapat kita simpulkan bahwa dari keempat ahli hadits mendapatkan kesamaan sanad melalui Anas bin Malik dan Qatadah bin Da'amah. Namun memiliki perbedaan sanad pada Abu Daud yang mendapatkan hadits melalui Sa'id bin Abi Urubah. Sedangkan ketiga ahli hadits lainnya mendapatkan dari Syu'bah bin Al Hajjaj.

Berdasarkan aplikasi web https://gethadith.web.app/ hadits tersebut terdapat pada Shahih Bukhari no. (pada kitab Fathul Bari urutan no. 7162), Shahih Muslim (pada Syarah Shahih Muslim urutan no. 2092), Sunan Abu Daud no. 3861 (pada syarah Sunan Abu Daud terbitan Baitul Afkar Ad Dauliah urutan no. 4214, 4215) dan Musnad Imam Ahmad no. 12259 dan 12399 (pada syarah musnad ahmad Muassasah Ar Risalah urutan no. 12720 dan 12864).

Berdasarkan hadits tersebut, terlihat jelas bagaimana seorang pemimpin harus memiliki tanda yang berbeda dengan bawahan. Tanda ini bisa tanda tangan, cap jempol, atau stempel yang hanya dimiliki oleh pemimpin tersebut. Dengan demikian, perintah yang diberikan pada bawahan melalui memo bisa dipertanggungjawabkan keasliannya. Sasa Djuarsa Sendjaja, dkk., memaparkan bahwa biasanya ketika orang memilih dan memutuskan untuk memakai pakaian tertentu, maka dia secara sadar telah menggunakan tanda nonverbal untuk mengekspresikan makna melalui kesan tertentu dalam penampilannya. ${ }^{48}$

Penggunaan cincin oleh merupakan bagian dari asesoris yang dipakai nabi yang sudah lumrah dalam budaya arab. Menurut Calero, cincin juga dapat mengirimkan pesan nonverbal, terutama cincin kawin. Bahkan di Irlandia disebutkan bahwa pernikahan tanpa cincin emas tidak sah. Orang Ibrani awal menggunakan cincin itu sebagai hadiah yang diberikan oleh keluarga laki-laki kepada keluarga calon pengantin perempuan. Bahkan ada penyebutan cincin dalam Alkitab, cincin disebut sebagai tanda kesetiaan dan persahabatan; Di

${ }^{48}$ Sasa Djuarsa Sendjaja, dkk., Teori Komunikasi Opcit. 6.20. 
Yunani modern ada dua jenis cincin, emas untuk pengantin pria, dan perak untuk pengantin wanita. Nilai yang lebih tinggi dari cincin untuk suami adalah tanda nonverbal dari superioritasnya. ${ }^{49}$ Namun bagi nabi, penggunaan cincin emas bagi laki dilarang dan diperbolehkan bagi perempuan untuk memakainya. Sementara banyak sahabat yang memakai cincin perak bahkan diantaranya digunakan untuk untuk meminang pada saat tidak memiliki harta sama sekali.

\section{KESIMPULAN}

Berdasarkan hadits-hadits tersebut, bisa kita lihat betapa pentingnya etika dalam sebuah komunikasi untuk mencapai tujuan komunikasi, yaitu pesan yang tersampaikan. Dalam hal ini perlu kita memperhatikan komunikasi kita baik verbal maupun nonverbal. Dengan demikian tidak ada kesalahpahaman yang terjadi akibat kesalahpahaman persepsi. Dari pembahasan diatas dapat kita simpulkan bahwa: Dalam melakukan komunikasi verbal, perlu bagi kita untuk mengulang sejelasjelasnya. Ditambahkan dengan etika yang dicontohkan nabi, yaitu mengucapkan salam dan meminta ijin mengulang jika komunikan masih belum paham. Dalam melakukan komunikasi nonverbal, hal-hal yang harus kita perhatikan adalah Bahasa tubuh, tanda, tindakan, obyek yang kita lakukan harus sesuai dengan etika islami. Sehingga bisa menunjukkan ketulusan, penghargaan, dan kenyamanan dalam berkomunikasi dengan komunikan.

\section{DAFTAR PUSTAKA}

Afriansyah, Ade. 2017. Konsep Pemimpin Ideal Menurut Al-Ghazālī. Jurnal NALAR Vol 1, No 2. Palangkaraya:IAIN Palangka Raya

Ainur, Muhammad. 2019. Gus Muwafik. Yogyakarta:Laksana

Aira, Aras. 2016. Pengaruh Etika Kerja terhadap Kinerja Manajerial pada Satuan Kerja Perangkat Daerah (SKPD) Kabupaten Kampar, Jurnal Kutubukhanah, Vol. 19 No. 1. Pekanbaru:UIN SUSKA

${ }^{49}$ Henry H. Calero, The Power of Nonverbal Communication, opcit, 158. 
Al-Id, Ibnu Daqiq. 2007. Syarah Hadits Arba'in. Sukoharjo: Pustaka Arafah

Alo Liliweri, 2015. Komunikasi AntarPersonal. Jakarta:Kencana

at-Tirmidzi, Imam. 1986. Asyamailul Muhammadiyah (Pribadi dan Budi Pekerti Rasulullah SAW), terj. M. Tarsyi Hawi. Bandung:CV Pernerbit Diponegoro

Basir, Siti Arni, dkk,. 2016. Peranan Pemimpin dalam Pelaksanaan Etika Kerja Islam: Kajian Kes di Johor Corporation (JCorp), Jurnal Usuludin 44. Kuala Lumpur:University of Malaya

Calero, Henry H. 2015. The Power of Nonverbal Communication How You Act Is More Important Than What You Say. Aberdeen: Silver Lake Publishing

Creswell, John W. Research Design Qualitative 3rd Edition. California:SAGE, 2009

Dahlan, Muh. Syawir. 2014. Etika Komunikasi Dalam Al-Qur'an dan Hadis. Jurnal Dakwah Tabligh, Vol .15, No. 1. Makassar:UIN Alauddin Makassar

Fathoni, M. Najmi. 2017. Strategi Komunikasi Model Sang Nabi. Jakarta:Gramedia

Handrini, Ninik. 2016. Berkata Baik atau Diam 294 Adab Kebiasaan Rasulullah SAW. Jakarta:Gramedia

Hardjana, Agus M. 2003. Komunikasi Intrapersonal dan Interpersonal. Yogyakarta:Kanisius

Harrison, E. Bruce dan Mühlberg, Judith. 2014. Leadership Communication: How Leaders Communicate and How Communicators Lead in Today's Global Enterprise. New York: Business Expert Press

Ikrar. 2012. Konsepsi Etika Komunikasi Menurut Al-Qur'an (Suatu Kajian Tafsir Tematik). Tesis Makassar:Pascasarjana UIN Alauddin Makassar

Kriyantono, Rachmat. 2019. Pengantar Lengkap Ilmu Komunikasi Filsafat dan etika ilmunya serta perspektif Islam. Jakarta:Prenadamedia Group

Moleong, Lexy. J. 2000. Metodologi Penelitian Kualitatif. Bandung: PT Remaja Rosdakarya.

Muhammad Aminuddin, Potret Risa Santoso, Rektor Cantik Termuda di Indonesia, https://news.detik.com/foto-news/d-4775596/potret-risa-santoso-rektorcantik-termuda-di-indonesia, (diunduh tanggal 16 Nopember 2019)

Murtado, Dodo. dkk. 2019. Manajemen dalam Perspektik Al Quran dan Hadits, Bandung:Yrama Widya

Navarro, Joe. 2014. Cara Cepat Membaca Bahasa Tubuh 2. Change Publications

Purwanto, Djoko. 2006. Komunikasi Bisnis. Erlangga:Jakarta

Robbins, Stephen P, Langton, Nancy, dan Judge, Timothy A. 2016. Organizational behavior Concepts, Controversies, Applications Seventh Edition. Toronto:Pearson

Sasa Djuarsa Sendjaja, dkk. 2014. Teori Komunikasi. Tangerang:Universitas Terbuka

Sari, A. Anditha. 2017. Komunikasi Antarpribadi. Sleman:DeePublish 
Satyagraha, Hadi. 2015. Kekeliruan Manajer. Jakarta:PT Elex Media Komputindo

Setyabudi, M. Nur Prabowo dan Hasibuan, Albar Adetary. 2017. Pengantar Studi Etika Kontemporer. Malang:UB Press

Supartha, Wayan Gede dan Sintaasih, Desak Ketut. 2017. Pengantar Perilaku Organisasi Teori, Kasus, dan Aplikasi Penelitian. Denpasar:CV Setia Bakti

Sulaiman, Muhammad dan Zakaria, Aizuddinnur. 2010. Jejak Bisnis Rasul terj. Gita Romadhona. Jakarta:Mizan

Timotius, K. H. 2016. Kepemimpinan dan Kepengikutan.Teori dan Perkembangannya. Yogyakarta:CV Andi Offset

Triningtyas, Diana Ariswanti. 2016. Komunikasi Antar Pribadi. Magetan:Ae Media Grafika

Wahyunanda Kusuma Pertiwi, Profil Menteri Pendidikan Nadiem Makarim, Lulusan Harvard yang Dirikan Gojek, https://tekno.kompas.com/read/2019/10/23/09431827/profil-menteripendidikan-nadiem-makarim-lulusan-harvard-yang-dirikan-gojek (diunduh tanggal 16 Nopember 2019)

Wattimena, Reza A. A. 2012. Menjadi Pemimpin Sejati Sebuah Refleksi Lintas Ilmu Jakarta, PT Evolitera

West, Richard dan Turner, Lynn H. 2008. Pengantar Teori Komunikasi, Edisi 3, Teori dan Aplikasi, terj. Maria Natalia Damayanti Maer. Jakarta:Salemba Humanika, 